\title{
ROKEYA SAKHAWAT HOSSAIN'S SULTANA'S DREAM: AN AVANT-GARDE OF ECONOMIC INDEPENDENCE OF WOMEN TOWARDS FREEDOM
}

\author{
Mahbubul Alam ${ }^{1}$, Nawshan Ara Rima ${ }^{2}$ \\ ${ }^{1}$ Jazan University, Jazan, Kingdom of Saudi Arabia \\ ${ }^{2}$ Islamic University, Kushtia, Bangladesh \\ E-mail:mahbub.ju80@gmail.com
}

Received: 18 August 2020

Accepted: 01 December 2020

\begin{abstract}
Critics and research scholars, so far have observed and considered Rokeya Sakhawat Hossain's (1880-1932) Sultana's Dream to be a feminist utopiaan imaginary place of ideal perfection or any non-existent society described in her considerable detail-overlooking main purpose, to an extent, in writing the novella. When the idea of female emancipation and awakening was completely unknown and unimaginable to Indian women in general, Begum Rokeya tried to instill its zeal in these ignorant women, got them to believe in their power, and showed a way of their ultimate freedom as something real and possible through a dream. The bitter discrimination she experienced in her own family as a girl, and the misfortune of the women of her society and women of undivided India bled her soft heart and urged her to work for the advancement and empowerment of women breaking all the traditional, social, cultural and religious barriers. In this regard, besides quality education, she believed that the first and the most important condition for female emancipation is self-reliance or economic independence where she differed from all other major contemporary feminists of the world for her unequivocal approach. The paper, therefore, aims at exposing the pathetic consequences of deprived and distressed women drowned under the dirt of illiteracy, fanaticism, superstitions, and prejudices showing the way they can be educated, economically solvent, self-reliant towards ultimate freedom and attributed state power and responsibilities which Begum Rokeya presents in the disguise of a dream in Sultana's Dream.
\end{abstract}

Keywords: emancipation, feminism, utopia, freedom.

\section{Introduction}

Sultana's Dream, first published in 1905 in the English periodical The Indian Ladies Magazine, is one of the earliest pieces of writings in English by an Indian woman Rokeya Sakhawat Hossain. Later, it appeared as a book from S.K. Lahiri and Company in Calcutta in 1908. In this story, "Sultana arrived in her dream, like Gulliver, in a place where the normal social situation was reversed. Men lived in the murdana or male zenana and tended to domestic chores while women belonged to the public world of politics and state management"(Hossain, 1992). Here, Begum Rokeya sketches a Lady Land where women are independent and free of seclusion and men are confined within the boundary of the house. 
Rokeya Sakhawat Hossain's Sultana's Dream: An Avant-Garde of Economic Independence of Women Towards Freedom, Mahbubul Alam, Nawshan Ara Rima

But the relation between men and women are not equal there; women are dominant and powerful and men are secluded in murdana- places for men inside the house. Men take care of the children, look after the house, and do all house-hold work like women in India. They are not fit for any skilled work outside the house. They don't have any participation in the development of the country as men in India thought of women at that time. Therefore, many readers and critics consider Sultana's Dream as terrible revenge on men for their patriarchal attitude towards women. Jahan (1988), in her book, quotes critic Abul Hossain who says,

The extreme measure of secluding men in Lady Land was a reaction to the prevailing oppression and vulnerability of our women.... Perhaps R.S. Hossain wrote this to create a sense of self confidence among the very vulnerable Bengali women.... That women may possess faculties and talents equivalent to or greater than men - that they are capable of developing themselves to a stage where they may attain complete mastery over nature without any help from men, and create a new world of perfect beauty, great wealth and goodness. (Hossain, 2005:2)

From this observation, it seems that Rokeya has portrayed the prevalent idea of gender in Indian society through the conversation between Sultana and Sister Sara in the story where Sultana represents the Indian stereotype and Sara presents the idea of Rokeya. Through the character of Sultana, Begum Rokeya satirizes the male-dominated patriarchal Indian society, customs, mal interpretation of religious scripts that tend to suppress women secluding them in zenana- inside the boundary of the house, deprive them of receiving education, and above all, get them dependent on men for their survival. On the other hand, she has expressed the idea of self-confidence, self-strength, and self-reliance through the character of Sister Sara in the Lady Land to encourage Indian women to believe in their infinite power to achieve economic independence for meaningful female emancipation.

\section{Literature Review}

The oppression and subjugation of women by the male-dominated patriarchal society has been one of the major concerns for the writers and critics around the world these days. Even in the Indian sub-continent, umpteen books and researches address the issue to alleviate the problems of women. However, the scenario was completely different throughout the 18th to 20th century when women were secluded inside the house and deprived of education and basic human rights in the name of fanatical social customs and religious sensibility in greater India. In such a state, as a girl of the world, Rokeya's experience in her own house as being deprived of education and secluded inside her house and the plight of women in her society encouraged her to work for the cause of women and to dream for a society where women would enjoy equal rights of men. Consequently, she expressed the dream of female emancipation and the rise of woman conspicuously in Sultana's Dream at the beginning of her literary career. Although Sultana's Dream pictures Rokeya's long and urges for female emancipation, she is not the only writer who brought the issue in front of the world stage at the beginning of the 20th century. Many other writers like Mary Astell, Daniel Defoe, Hannah More, Catherine Macaulay in the west talked about the issue even before Begum Rokeya and most of them emphasized the necessity of limited education either to be a better mother or to be a well- mannered wife. Nevertheless, the issue of female freedom was not a central concern for them. 
It was Wollstonecraft (1759-1797) who, for the first time, discerned and emphasized complete education for women to enrich all of human society in her A Vindication of the Rights of Women. Wollstonecraft says, "Men and women must be educated, in a great degree, by the opinions and manners of the society they live in." She also wants an equal and quality education for the woman that enables them to become enlightened citizens of the country and earn their subsistence, and recognizes that woman, as a man, is a creature of thoughts, feelings, and reasons. Apart from education, it seems that Wollstonecraft has talked about the necessity of economic independence of women in some places or others in her vindication. In chapter-IV, she says, "Happy is it when people have the cares of life to struggle with, for these struggles prevent their becoming a prey to inervating vices, merely from idleness" (Wollstonecraft, 2004: 71). She suggests her women earn their bread through work. "It is true", she says of dependent women, "they are provided with food and raiment, for which they neither toil nor spin; but health, liberty, and virtue are given in exchange" (Wollstonecraft, 2004: 72-3). Apparently, though it seems that she wants her women to stand on their own, she actually laments here for those women who lost their earning with a dairy farm, a small brewery, or in a domestic industry because of industrialization throughout Europe during the last part of 18th century. It is obvious when Wollstonecraft says in chapter IX, "How many women thus waste life away the prey of discontent, who might have practiced as physicians, regulated a farm, managed a shop, and stood erect, supported by their own industry..." (Wollstonecraft, 2004: 185). On the other hand, she has her limitations regarding her intention of economic independence of women. She has directed her argument only to the middle-class women eradicating upper class and lower class women from her reformed society. Despite all her concerns about the economic independence of women, above all, she depends on men to free women as she says in Chapter XII, "make women rational creatures, and free citizens, and they will quickly become good wives, and mothers; that is - if men do not neglect the duties of husbands and fathers" (Wollstonecraft, 2004: 222).

John Stuart Mill (1806-1873) in his Subjection of Women has also talked about the economic independence of women. He believes that "the power of earning is essential to the dignity of women" (Warren, 2009: 384). But immediately after this he makes a paradoxical statement and says that the character of a married woman's life, however, must still be primarily domestic, her education a source of spiritual enrichment rather than how she gains economic independence.

Virginia Woolf (1882-1941), the closest contemporary of Begum Rokeya also explores the deplorable condition of women in her society. Her writings like A Room of One's Own and Mrs. Dalloway reflect the suppression of women in Victorian society as a whole. (Zaman, Sultana \& Shurovi: 2016) in their paper "Women in Virginia Woolf and Begum Rokeya: A View from Western and Islamic Perspective" observe that women were insignificant and could not articulate their mental agony because of fear, shame, and rejection of the Victorian male-dominated patriarchal society that did not encourage them to attend universities or to participate in intellectual debate. Apart from talking about the oppression of women, it seems that Virginia Woolf talks about the financial affairs of women as she criticizes her own biased and prejudiced society for not providing women a congenial environment to exercise their imagination to become a writer and get equal payment of men. It is evident when the omniscient narrator of Woolf (2012), in her A Room of One's Own decries with a moan: 
if only Mrs. Seton and her mother and her mother before her had learnt the great art of making money and had left their money........ we might have looked forward without undue confidence to a pleasant and honorable life time spent in the shelter of one of the liberally endowed professions (Hossain, 2005:42).

Woolf believes that women must have money and a room of her own to be a great writer, which may entirely change women's relationship with men. In this regard, she proposes that only women of higher class and private means can think of taking up the pen and write fiction to earn money. In doing so, Wolves disregards lower class illiterate women in general and could not show any way to these women to earn their livelihood, whereas Begum Rokeya dreams of a society where women from all classes and all religion earn their livelihood.

Nineteenth and twentieth-century India witnessed a lot of prolific writers and social reformers like Ram Mohan, Keshob Chandra, Akhsoy Datta, Radha Nath Shikder, Perichand Mitra who thought about the rights of women in a society profoundly. According to (Alam: 2009), the main purpose of all reform-attempts was to tear the fetters of womenhood and establish their rights restraining Sati, forbidding polygamy, allowing widow-marriage, resisting the practice of aristocracy and spreading female-education (Alam, 2009: 40). Regarding female freedom and education (Kopf, 1975) observes that Bengali reformers, Brahmo and otherwise, still held the nation first propagated widely in 1855 by Akhoy Kumar Dutt and Vidyasagar, that Hindu social reform in Bengal must start with the emancipation of women. Because women played such a crucial role in shaping the character and thought of children, it was essential that they be educated properly. On the other hand, "Keshab Chandra always believed that no substantial progress in society was possible without first emancipating women from the fetters of ignorance, superstition and inhibiting customs... a solid education should be given to women if their miseries were to be alleviated" (Sinha, 1968: 251). It seems that the main purpose of their writings and reform activities was to raise awareness of female distress wishing for its remedy. However (Hasan, 2008) observes that though they used the term 'female emancipation' in some or other places, it was completely absent from their writings if it means the acknowledgment of female independent personality. (Hasan, 2008: 121).

Few writers like Faizunnesa and Kazi Imdadul Haque, Taherunnesa, and Latifunnesa in Indian Muslim society also wanted to spread education among women for the sake of the development of society. In this regard, the observation of Kazi Imdadul Haque is worth to mention, "Now it seems that we don't have any hope of development without spreading education. Especially female education is a must to spread immediately. There is no way out of it" (Hasan, 2008: 121). Though they realized the necessity of spreading education among women, they wanted limited education for them to be an ideal housewivfe and a good mother.

In this regard, Rokeya's thought is very much distinct and radical even at present times and wonders us. She believes that education is indeed a primary requirement for female freedom that she expressed in her writings like Women's Downfall and Padmarag. At the same time, she thinks that only education is not enough to attain freedom. According to Rokeya, the first and most important condition of freedom for women is economic freedom or self-reliance besides education that she has shown vividly in Sultana's Dream. Because of this reason, she planned this novel to get Indian women to believe in their infinite power as 
revenge and protest against the unjust and oppression of male-dominated patriarchal society. Her purpose was to make women conscious of their distressed state, infuse a desire for freedom inspiring them with the courage to stand on their own through economic independence.

\section{Research Method}

A qualitative descriptive method has been employed to analyze the data collected from primary and secondary sources to achieve the main objective of the current study. Primary sources here refer to the works of the writer Begum Rokeya from where the researcher has directly collected data in the form of notes. In this research study, the novella Sultana's Dream has been used as a primary source along with her some other writings like Women's Downfall and Padmaragh by Rokeya Sakhawat Hossain. All the quotations, sentences, and words related to the main idea of the research have been examined and investigated through a thematic and textual analysis approach. Consequently, all the information about the oppression of women, the status of women under repressive patriarchal the then Indian society and economic affairs from these works have been collected in the form of notes to compare and contrast with the other writers written on the same idea. Secondary sources here refer to the research works done by other research scholars, critics, and writers on the literary pieces of Begum Rokeya available in the form of books, book chapters, journals, articles, and websites. Information from all these sources related to the main idea of the research has also been carefully collected and analyzed in the current study. However, a thorough literature review has also been conducted to show the contribution of other prominent writers like Marry Wollstonecraft, John Stuart Mill, and Virginia Woolf in their major works along with some other writers from the West and the East in the same field. The researcher has made a comparative study between the contribution of these writers and the contribution of Begum Rokeya based on the analysis of the primary and secondary data to show Begum Rokeya as an advocate of the economic independence of women towards freedom.

\section{Results and Discussion}

At the beginning of the story of Sultana's Dream, Begum Rokeya has depicted the real plight of Indian women and the freedom of woman in a lady- land through a dialogue between Sultana and Sister Sara. When they were walking in the street of the lady- land on a fine morning, Sultana was 'feeling shy' since she walked 'in the street in broad daylight'. She also said, "I feel somewhat awkward. As being a purdahnishin or veiled woman I am not accustomed to walking about unveiled." (Bagchi, 2005: 143) Such a very simple statement of Sultana is enough to understand the condition of Indian women of that time. Women did not have any right to walk in the street even without a veil if men see their faces. They had a very limited excess to the outer world. Here Rokeya is very critical about the prevalent purdah observation of Indian women particularly in Muslim society. It does not necessarily mean that she was against this purdah. Rather she maintained purdah throughout her life. But she was against the strict and unjustified purdah a lot of women maintain in Indian society. Rokeya considers such purdah as an obstacle in their way of advancement of women. In her other work, Oborodhbashini or Secluded Ones (Hossain, 1931/1988: 2) has reported some incidents of observing purdah in different parts of India. One such report is like: 


\begin{abstract}
"Once, a house caught fire. The mistress of the house had the presence of mind to collect her jewellery in a hand bag and hurry out of the bedroom. But at the door, she found the courtyard full of strangers fighting the fire. She could not come out in front of them. So she went back to her bedroom with the bag and hid under her bed. She burnt to death but did not come out. Long live purdah!"
\end{abstract}

These women maintained purdah not only against men but also against women of other families. Married women tried to hide even from a gypsy woman. Unmarried girls were not allowed to go in front of women except their maidservants and near relatives. Even a wealthy urban woman observed purdah against an unveiled Hindu and Christian missionary women. It was almost like the woman who could hide more in the corner of the house was considered more aristocratic.

Although Rokeya was critical about the purdah observation of Muslim society, she was equally aware of the oppressions and exploitations of the women of other religions. Like Muslim women, many Hindu girls were forced to maintain purdah custom. During the classical era of Hindu culture, when India's economy was flourishing and many foreign traders and rulers came to visit the country, to protect women from these foreign influences, "Upper caste women were placed in the inner apartments of their houses and used the veil when they went out" (Quayum, 2017: 54). This veiling custom was also very prominent among Hindu women in the north and central India. As a part of respect relations, these women used to veil their faces before their husbands', elder male relatives, and the people of the village into which she comes as a stranger after marriage. This custom taught them how to behave in the social order- with whom they may interact and communicate. (Sharma, 1978) notes that veiling teaches a Hindu woman "the distinction between those situations in which she ought to be passive and submissive and those in which some degree of responsible activity and control are allowed her." In her writing the Abarodhbasini or Secluded Ones (Hossain, 1931: 391) reports another incident of Hindu purdah customs:

A Hindu bride from western region of India went for a bath in the river Ganges with her mother in law and husband. After taking bath she couldn't find them in the crowd. At last she started walking behind a gentleman. In the meantime, police raid the area to search the bride and caught the gentleman saying you are abducting the wife of $X$. Out of his surprise, he found the bride standing behind him and holding the loose part of the knot of his cloth. Being questioned, the bride said that since she always keeps long veil, she couldn't see her husband very well. She saw her husband wearing a dhuti (a long piece of cloth) with yellow stripe. Since this gentleman wore a dhuti with yellow stripe, she was under the impression that he was her husband and started to follow him.

These are the ways Indian women both Muslim and Hindu observed purdah in their society which, very often, reduced them to invisible object and an object of derision. This practice of purdah is also deadly and devastating for women at the same time. In the name of religion, they were bound to follow this custom by the patriarchal society. Consequently, women were advised to keep themselves inside the house known as zenana. This state of women is again satirized by Sister Sara in Sultana's Dream. According to Sara, this is quite unfair to shut innocent women in zenana whereas Sultana feels safe in it. However, besides 
these women live in utter seclusion, they are exploited in many other ways which is evident from the speech of Sultana as she says to Sister Sara:

"We have no hand or voice in the management of our social affairs. In India man is lord and master. He has taken to himself all powers and privileges and shut up women in the zenana." (Hossain, 2005: 5)

Begum Rokeya has reflected the pathetic consequences of the misfortune of the life of Indian Women through this statement of Sultana. Gender discrimination is obvious in every sphere of life. The relation between men and women is like that of a master and a slave. Women do not have any choice, any voice, any independence, or any participation in sociopolitical activities. Men consider them like a drawing-room object without any physical movement. There is no spirit in her body and mind. Her head and heart have become perpetually weak living in utter seclusion in zenana. It is something like they are born to be dependent on men leading them to complete slavery. Rokeya has depicted this state of women in her another work Women's Downfall:

"This is because for a very, very long time all the higher faculties of women have been nipped in the bud, so that their outer and inner personalities, brain, heart, everything, have become slaves. We no longer have selfdependence or force in our heart." (Hossain, 2015: 23)

Begum Rokeya, as a girl of the world, was moved by these devastating and tragic conditions of women. She thought of a number of possible ways to turn them into a better life and empower them. She finally came up with Sultana's Dream as a remedy for the destitute Indian women challenging the traditional male dominated social conducts and malinterpretation of religious scripts by so-called scholars. Rokeya has tried to encourage them to believe in their power through the achievements of Sister Sara and the women of the Lady Land as a whole. From the yard of a house to the Queen's palace of the country, women have a great contribution to every aspect of life. From the beginning to the end of the story, Sister Sara talks about her work at home, in the laboratory, the Universities for women where all professors are also women, and the contributions of women in science and technology. She also canvasses the encouragement and patronization of the good queen in different social welfare projects and activities that reflect Rokeya's idea of economic independence, one of the most important requirements for women's empowerment towards freedom.

All women in the Lady Land are hard-working and very much dedicated and professional to their sphere of work. Equally, they work at home and in their offices with great patience. In this way, they earn their livelihood. Sister Sara is very much skillful in embroidery, knitting, and needlework for household decoration. At the same time, she works in a laboratory that provides her economic independence. This idea is clearly expressed in a short conversation between Sultana and Sister Sara:

'Have you done all this work yourself?' I asked her pointing to the various pieces of embroidered teapoy cloths?

'Yes.'

'How can you find time to do all these? You have to do the office work as well? Have you not?'

'Yes. I don't stick to the laboratory all day long. I finish my work in two hours.' (Hossain, 2005: 6) 
Rokeya Sakhawat Hossain's Sultana's Dream: An Avant-Garde of Economic Independence of Women Towards Freedom, Mahbubul Alam, Nawshan Ara Rima

Furthermore, Begum Rokeya has emphasized education for women to enable them to work in different social institutions, to contribute to the development of the country as a whole. The underlying idea behind spreading education among women is to get them selfreliant, solvent economically, and earn their bread without depending on others. Therefore, the Queen of Lady Land, who loves science and technology, "circulated an order that all women in her country should be educated. Accordingly, a number of girls schools were founded and supported by the government and education has spread far and wide among women." (Hossain, 2005: 7)

There are two Universities, run by lady principal of course, in the capital of the Lady Land where women engage themselves with different scientific researches and inventions. The lady staffs of these Universities are always in a competition to invent something new. The ladies of one University invented a wonderful balloon by which they can draw as much water they need from the atmosphere whereas the other invented an instrument by which they can collect as much solar heat as they want. Later, in the novel, these inventions have proved very much useful for social development and the security of the country. When male soldiers failed to protect their country from a foreign invasion, "Lady Principal along with her two thousand students marched to the battlefield, and arriving there directed all the rays of the concentrated sun-light and heat towards the enemy" (Hossain, 2005, p. 10) and defeated them completely.

They cultivate lands that are tilled utilizing electricity. They draw rainwater as much as they need for cultivation through a water balloon. They sprinkle the ground with plentiful showers drawn from artificial fountains during summer and keep their rooms warm with solar heat in winter. They are also busy in aesthetic activities of the country as Sister Sara says:

We are all very busy making nature yield as much as she can. We do not find time to quarrel with one another as we never sit idle. Our noble queen is exceedingly fond of botany; it is her ambition to convert the whole county into one grand garden. (Hossain, 2005: 12)

However, this great achievement of women of the Lady Land came through education and the development-oriented mentality and patronization the Great Queen as she says:

"We dive deep into the ocean of knowledge and try to find out the precious gems, which nature has kept in store for us. We enjoy nature's gifts as much as we can." (Hossain, 2005: 14)

Throughout this whole process of education, women learn, teach, work in 'laboratories', 'manufectories' and 'observatories' which reflect nothing but their self- reliance and economic independence.

The idea of economic independence, a mere dream in Sultana's Dream, finds its real ground as a proposal in her other essay Women's Downfall for alleviating the misfortune of women and as a means of freedom. Rokeya believes that the speech of female freedom is meaningless in a society where they completely depend on their husbands economically. She, therefore, asks women to start their job, trade, and business to be self-reliant. She also gives a clear guideline for the women to attain economic freedom:

"Firstly, we must have the will and an unwavering resolve to work alongside the men in all affairs of life. We should also have a firm conviction that we were not born as slaves. We will do all we have to in 
order to attain equality with the men. If earning a livelihood freely brings our freedom, then we will do that. If need be, we will begin by becoming clerks and then magistrates, barristers-at-law, judges; we will work in every profession" (Hossain, 2011).

However, Begum Rokeya has implemented the idea of economic independence, which was a dream in Sultana's Dream, and a proposal in Women's Downfall, in her other famous work Padmarag[Rubi]. Here in this novel she has brought all destitute women from different religion and different corner of the country to the workshop of Tarini Bhavan where they work together like sisters:

"In the workshop, all categories of women- spinsters, wives and widowswere to be found. They were occupied in various kinds of work- sewing, spinning, weaving cloth on a loom, binding books and preparing different types of sweet meats and selling them. Some were given training that would make them eligible for a teaching job; some learnt typing, while others trained to become nurses. To sum it up, the women belonging to this section earned their own living." (Hossain, 2005:31)

According to Rokeya, the economic independence of women is a means to the development of the country. Since women constitute half of the society, it is completely impossible to develop a society without changing the economic status of women. Through the success stories of women in the Lady Land, she tries to inspire the enslaved Indian women to believe in their own will power, achieve knowledge, work hard, earn their livelihood and ensure economic independence towards freedom. "She impels women to walk side by side with men in both the material and spiritual spheres of life and suggests Indian women not to become a terrible burden, rather become a companion, a co-worker and a lover of men in the way to the progress of the society" (Alam, 2013, p. 663).

But Begum Rokeya didn't confine herself only in writing for the cause of Indian women. She shouldered a great responsibility of reforming the then society. As part of her reform activities, she established a girls' school in Calcutta known as Sakhawat Memorial Girls School on 16 March 1911 despite many obstructions from so-called social reformers and religious scholars of the then patriarchal society. She wanted wholeheartedly Indian women to achieve a proper place in all spheres of life. She also founded Anjuman-i- Khawatin-i-Islam in 1916 intending to gear the movement of female emancipation of Bengali Muslim women for the greater sake of the country. The activities of this organization were "setting up of vocational training centers for women from financially deprived backgrounds, providing aid for widows in distress, helping young girls from unprivileged backgrounds to settle down by getting them married of and persuading educated women to teach in slums and train their residents for different kinds of income - generating work" (Bagchi, 2005: x).

\section{Conclusion}

Now it seems that Begum Rokeya, for the first time, connected the idea of economic independence of women to the movement of female emancipation whereas most of her contemporary writers, social reformers, and philosophers both in the West and East emphasized restricted education. Although Mary Wollstonecraft raised the issue in her Vindication to the Rights of Women, it was so narrow and dispersed in supplication since she excluded lower and upper-class women from her vindication. John Stuart Mill, on the other 
Rokeya Sakhawat Hossain's Sultana's Dream: An Avant-Garde of Economic Independence of Women Towards Freedom, Mahbubul Alam, Nawshan Ara Rima

hand, realized the necessity of earning money for the dignity of women. But he placed them in the domestic affairs and urged them to be educated for their spiritual development. Virginia Woolf also talked about the financial benefits of women as a writer and demanded equal payment like men. In the end, she too was concerned only about the educated and aristocratic women to earn money through pen disregarding the middle and lower class illiterate women in general. Rokeya, in this regard, differs completely from these writers in terms of education and economic independence. According to Rokeya, the purpose of education for women is not only to develop their spiritual faculty to become a good daughter, a good wife, and a good mother but also to develop their rational being for the socio-economic and cultural development of the country. She believed that the speech and discussion of emancipation are impossible in a society where women depend on men economically. It is Rokeya who understood the necessity of self-reliance and economic independence and urged Indian women from all caste, class, and religion to rise from their life long bondages and from their dependence on men and become a useful and competent citizen of the country. Therefore, the freedom Indian subcontinental women enjoy today, their equal participation in education, job field, and national politics, and their ability to lead the nation as well are the resultants of the successful implementation of the dream of Begum Rokeya which she dreamt in Sultana's Dream before one hundred years ago.

\section{References}

Alam, M. (2013). Rokeya Sakhawat Hossain: An Unknown Voice of Bengal. Sino- US English Teaching, 10(8), 663. http://www.asiaticsociety.org.bd/journal/H_December_2015/ 5\%20H_896_D2015.pdf.

Alam, M. S. (2009). Rokeya Sakhawat Hossain: Jiban O Shahittyakarma[Rokeya Sakhawat Hossain: Life and Literary Works]. Dhaka: Bangla Academy.

Bagchi, B. (2005). Rokeya Sakhawat Hossain: Sultana's Dream and Padmarag. New Delhi: Penguine Books.

Hasan, M. S. (2008). Begum Rokeya: Somoy O Sahitya[Begum Rokeya: Time and Literarture]. Dhaka: Mowla Brothers.

Hossain, R., S. (1931). Rokeya Rachanabali [Works of Rokeya]. (A. Kadir, Ed.). Dhaka: Bangla Academy.

Hossain, R.S. (2005). Sultana's Dream and Padmarag. (B. Bagchi, Trans.). New Delhi: Penguine Books. (Original work published 1905)

Hossain, R., S. (2011). Istrijatir Abanati [Woman's Downfall]. (M.A. Quayum, Trans.). Transnational Literature , 4(1), 6. (Original work published 1903). https://icsai.org/procarch/7icllce/7icllce-051.pdf.

Hossain, R. S. (2015). Motichur: Sultana's Dream and other writings. (R. Roy \& P. Bandyopadhyay, Trans.). New Delhi: Oxford University Press.

Hossain, Y. (1992). The Begum's Dream: Rokeya Sakhawat Hossain and the Broadening of Muslim Women's Aspirations in Bengal. South Asia Research, 12(1), 1. https://www.researchgate.net/publication/273898717_Commemorating_Rokeya_Sa khawat_Hossain_and_Contextualising_her_Work_in_South_Asian_Muslim_Feminism

J. Warren, K. (2009). An Unconventional History of Western Philosophy: Conversations between men and women philosophers. Maryland: Rowman and Littlefield Publishers.

Jahan, R. (1988). Sultana's Dream: A Feminist Utopia and Selections from the Secluded Ones. New York: The Feminist Press. 
Kopf, D. (1975). The Brahmo Idea of Social Reform and the Problem of Female Emancipation in Bengal. in J. R. Mclane(Ed.), Bengal in the Nineteenth and Twentieth Centuries ( $p$. 46). Michigan: Asian Studies Center, Michigan State Univercity.

Quayum, M. A. (2017). Inspired by the Bengal Renaissance: Rokeya's Role in the education and Emancipation of Bengali Women. In M. A. Hasan(Ed.), A FEMINIST FOREMOTHER: Crirical Essays on Rokeya Sakhawat Hossain (p. 54). Hyderabad: Orient Blackwan Private Limited.

Sharma, M., U. (1978). Women and Their Affines: The Veil as a Symbol of Separation. Man, New Series, 13(2), 226. https://www.scribd.com/document/142736800/SharmaWomen-and-Their-Affines.

Sinha, N. (1968). Freedom Movement in Bengal. Calcutta: Education Dept., Govt. of West Bengal.

Woolf, V. (2012). A Room of One's Own. Hertfordshire: Wordsworth Classics.

Wollstonecraft, M. (2004). A Vindication of the Rights of Women. London: Penguine Books.

Zaman, F., Sultana, M, \& Shurovi, M. (2016). Women in Virginia Woolf and Begum Rokeya: A View from Western and Islamic Perspective. IOSR Journal of Humanities and Social Sciences, 21(2), 31. http://www.iosrjournals.org/iosr-jhss/pages/21(2)Version-1.html. 